\title{
The Association for Asian Studies: Summary of the Year 1957-58
}

Membership and circulation of the Journal of Asian Studies. The information customarily given in this part of the annual report on the status in 1958 of the size of the membership, their classification by professional field, professional status, geographical area of primary interest, the number of non-member subscrip- tions, and the total circulation of the Journal, etc., are to be found in the preceding report in Appendices I and II.

Treasurer's Report. The following is a summary of the Treasurer's Report for the calendar year 1957.

\section{A. SUMMARY OF CASH CHANGES}

General fund

Cash Balance $1 / 1 / 1957$

$\$ 13,168.24$

Special Funds:

General expansion (Ford).

Expansion and improvement of journal (Ford)...

Monograph Series (Rockefeller-Ford) ............

South Asia Committee (Rockefeller) . ............

Asia Foundation Lectureship.................

Committee on Chinese Thought (Rockefeller)....

Committee on South Asian Languages (Rocke-

feller).

Totals
$32,371.00$

$10,048.97$

$10,262.82$

897.22

782.01

(501.04)

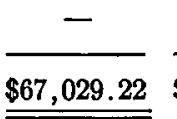

Receipts

$\$ 33,692.95$

466.57
-
$11,136.99$
$2,628.48$
$4,000.00$
$24,868.00$

$3,120.00$

$\$ 79,912.99$
Disbursements $\$ 26,287.74$

$16,694.36$

$5,048.97$

$3,621.55$

$2,751.40$

$2,878.04$

$13,865.67$

854.93

$\$ 72,002.66$
Cash Balance

$12 / 31 / 1957$

$\$ 20,573.45$

$16,143.21$

$5,000.00$

$17,778.26$

774.30

$1,903.97$

$10,501.29$

$2,265.07$

$\$ 74,939.55$

\section{B. RECEIPTS}

\section{General Fund}

Memberships:

New....

Renewals.

Journal :

New Subscriptions:

Institutions. .

Individuals.

Renewal Subscriptions:

Institutions. ...

Individuals.

Single Copies:

Quarterly...

Bibliography

235.81

Microfilm Royalties.

$1,242.74$

Advertising.

.....................

Sale of Mailing Lists

$1,168.75$

153.41

125.00

Reproduction Royalties from Governmental Agencies...............

$6,358.55$

Ford General Expan

Registration.

Exhibits and Program Ads.

Luncheon 
Sale of Membership Lists

46.00

Service Charges Against Grants:

South Asia Committee

$\$ 66.66$

Asia Foundation Lectureship. .

Committee on Chinese Thought.

$1,797.78$

488.00

Interest on Investments.

.

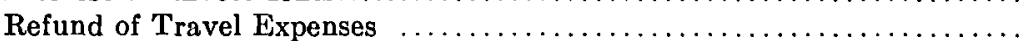

Grants from Ford Foundation for Expansion of Journal

For Year 1955.

Balance Due for Year 1956

$\$ 2,500.00$

48.97

For Year 1957

$2,500.00$
$2,352.44$

$1,587.78$

243.17

$5,048.97$

23.44

$198.62 \$ 33,692.95$

Miscellaneous Refunds.............................
Newsletter Allocation from South Asia Committee

\section{Special Funds}

General Expansion (Ford):

Refund of 1956 Newsletter Expense

Monograph Series:

Interest on Investments.

$\$ 1,011.54$

Grant from Ford Foundation

Sales of Elliott Monograph.

Sales of Swisher Monograph.............................. $\quad \mathbf{7 . 5 0}$

Refund of 1956 Office Expense from General Fund................. 96.00

South Asia Committee:

Grant from Rockefeller Foundation

Asia Foundation Lectureship:

Grant from Asia Foundation...

Committee on Chinese Thought:

Grant from Rockefeller Foundation.

Committee on South Asian Languages:

Grant from Rockefeller Foundation

Total Receipts.

\section{DISBURSEMENTS}

\section{General Fund Expenditures}

\section{Journal:}

Publication Costs-Journal

$\$ 11,576.93$

Publication Costs-Bibliography.................. $\quad 4,393.36$

Maintain Address Files . . . . . . . . . . . . . . . . . . . . $\quad 192.17$

Editorial Costs-Journal............................ $\quad 228.26$

Editorial Costs-Bibliography........................ $\quad 596.35$

Cost of Journal Reprints............................ $\quad 183.80$

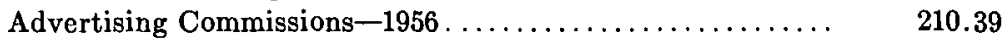

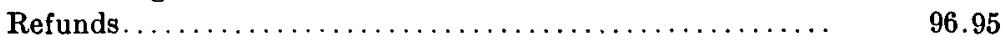

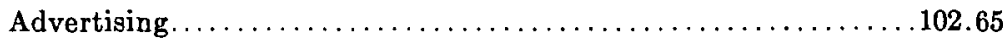




\begin{tabular}{|c|c|c|}
\hline Annual Meeting: & & \\
\hline Luncheons..... & $\$ 535.80$ & \\
\hline$\ldots \ldots \ldots \ldots \ldots \ldots \ldots \ldots \ldots \ldots \ldots \ldots \ldots \ldots$ & 183.02 & \\
\hline 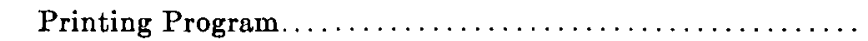 & 236.76 & \\
\hline 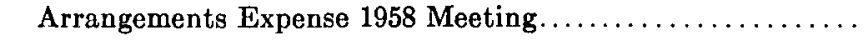 & 114.25 & \\
\hline 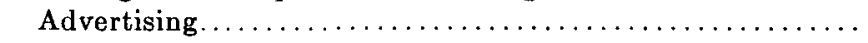 & 135.00 & \\
\hline Advertising Commissions-1956. & 122.11 & \\
\hline Miscellaneous Expenses..... & 186.46 & $1,513.40$ \\
\hline Newsletter-Publishing and Mailing. . & & 660.98 \\
\hline Travel Expenses--Refunded $\ldots \ldots \ldots \ldots \ldots \ldots \ldots$ & & 243.17 \\
\hline Secretariat: & & \\
\hline Salary-Manager... & $\$ 3,892.87$ & \\
\hline 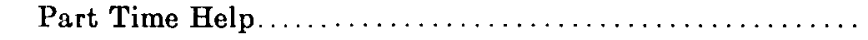 & 375.00 & \\
\hline Office Supplies and Expense $\ldots \ldots \ldots \ldots \ldots \ldots \ldots \ldots \ldots \ldots \ldots \ldots \ldots \ldots$ & 865.23 & \\
\hline Telephone and Telegraph $\ldots \ldots \ldots \ldots \ldots \ldots \ldots \ldots \ldots \ldots \ldots \ldots$ & 271.64 & \\
\hline 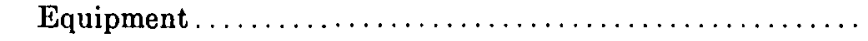 & 14.37 & \\
\hline Addressing Services $\ldots \ldots \ldots \ldots \ldots \ldots \ldots \ldots \ldots \ldots$ & 90.67 & \\
\hline 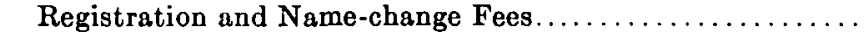 & 73.97 & \\
\hline Miscellaneous Expense $\ldots \ldots \ldots \ldots \ldots \ldots \ldots \ldots \ldots$ & 94.35 & $5,678.10$ \\
\hline Monograph Office Expense & & 154.21 \\
\hline Membership Committee... & & 105.05 \\
\hline Treasurer's Office: & & \\
\hline Audit. . & $\$ 150.00$ & \\
\hline 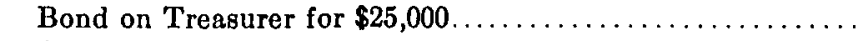 & 62.50 & \\
\hline 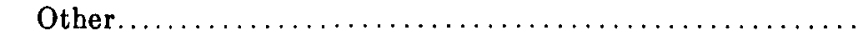 & 139.47 & 351.97 \\
\hline
\end{tabular}

\section{Special Funds Expenditures}

General Expansion (Ford)

$16,694.36$

$5,048.97$

Expansion and Improvement of Journal (Ford) $\ldots \ldots \ldots \ldots \ldots \ldots \ldots \ldots \ldots \ldots \ldots$

$3,621.55$

Monograph Series (Rockefeller and Ford) $\ldots \ldots \ldots \ldots \ldots \ldots \ldots \ldots \ldots \ldots \ldots \ldots$

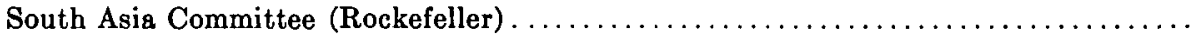

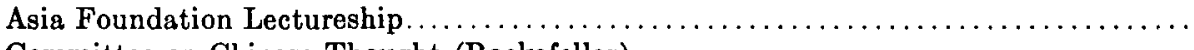

Committee on Chinese Thought (Rockefeller) $\ldots \ldots \ldots \ldots \ldots \ldots \ldots \ldots \ldots \ldots \ldots \ldots$

Committee on South Asian Languages (Rockefeller).

$2,751.40$

$2,878.04$

$13,865.67$

854.93

Total Disbursements .

Report of the Editor of the Journal of Asian Studies. During the past year the Journal has been further expanded, reaching the size of 1,007 pages for the five numbers, August 1957 through May 1958. This represents an increase in one year of 160 pages, and is 400 pages larger than the Journal of three years ago. Total circulation stood at 1,984 copies in March of 1958 .

During the year gross income from advertising stood at $\$ 1062.50$, as compared with $\$ 1,681.30$ in the preceding year. Mr. Edwin L. Neville, Jr. continued to serve as Advertising Manager during 1957. The net cost of publishing and distributing the five numbers which appeared during 1957 was $\$ 14,766.85$ as compared with a net cost of $\$ 10,207.80$ during the previous year. There were, however, other costs of clerical and managerial assistance provided by the Secretariat and indirect subsidies provided by several institutions. These costs and contributions are not included in the above statement of cost to the Association.

Of the total of 1,007 pages in the five numbers, 228 pages consisted of articles, 4 pages of notes, 
95 pages of review articles, 308 pages of reviews, 74 pages of news of the profession, and 269 pages of bibliography. This represented an increase in the number of pages devoted to each category, over the previous year, with the exception of the number of pages devoted to articles.

Of the articles published six, covering 102 pages, were concerned with China, one of 26 pages dealt with Japan and Korea, four dealt with Southeast Asia in 22 pages, five concerned South Asir and came to 78 pages. Three articles were in the field of history, three in political science, and a like number in languages and literature. Sociology and anthropology received two articles, while economics had one article.

A total of 167 book reviews were published in the Book Review section under the editorship of Professor Joseph R. Levenson. Forty-one additional books were reviewed in review articles. Of the 167 reviews in the regular book review section, 33 reviews dealt with General Asia, 39 with China, 33 with Japan and Korea, 28 with South Asia, 26 with Southeast Asia, and 8 with Central Asia. It is planned to limit the number of reviews during 1958 in order to accomodate more articles.

Professor Robert I. Crane served as editor of the News of the Profession section of the Journal. A series of reports on Asian Studies in England and Europe was begun in the August 1957 Number.

Mr. Howard P. Linton continued to serve as General Editor of the Bibliography Number, issued in September 1957 under the new title Bibliography of Asian Studies (formerly Far Eastern Bibliography). The Bibliography has been expanded in two years from 111 pages to 269 pages.

Report of the Editor of the Monographs of the Association for Asian Studies. Professor E. A. Kracke relinquished the editorship at the end of June 1957 and his post was assumed by Professor L. Carrington Goodrich. One monograph was then in press, Walter F. Vella, Siam under Rama III, 1824-1851, and has been published by J. J. Augustine. A second monograph, G. William Skinner, Leadership and Power in the Chinese Community of Thailand, published by the Cornell University Press, appeared in April.

The Monograph Board has agreed to assume half the cost, provided it comes to no more than $\$ 500.00$, of the publication of John Mason
Brown's Thailand Bibliography by the University of Florida Libraries Bibliography Series. The Board has also accepted for publication, Charles D. Sheldon, The Rise of the Merchant Class in Tokugawa Japan 1600-1868: An Introductory Survey. Three other manuscripts are currently being revised by their authors with a view to being accepted by the Board, while seven other manuscripts are currently under consideration.

Of the $\$ 20,000$ received from the Ford Foundation and the Council on Economic and Cultural Affairs, some $\$ 7,700$ has been spent or committed, and the Skinner volume will cost approximately $\$ 2,750$. Royalties to date total $\$ 485.55$ and accrued interest on capital funds amounts to $\$ 1,011.54$.

The Tenth Annual Meeting of the Association for Asian Studies was held at the Sheraton-McAlpin Hotel in New York City, April 1-3, 1958. Local arrangements were made by Ward Morehouse of the Asia Society and his committee. The program was arranged by a committee under the direction of Professor Robert I. Crane, University of Michigan. Hugh Borton, President of the Association, presented his address, "Asian Studies and the American Colleges," at the Annual Luncheon. The Tenth Annual Meeting was held in joint session with the American Oriental Society and both associations were tendered an extremely well-attended cocktail party by the Asia Foundation, the Asia Society, the Japan Society, Columbia University, and New York University. Attendance at the 1958 meetings set a new record, with over 625 registered and present.

Association business was conducted at the meeting of the Officers and Directors on March 31 and of the Monograph Board on April 2. The general business session met the same afternoon. At the latter session new officers, directors, and committee members were announced as follows:

Officers: President, John K. Fairbank; VicePresident, George B. Cressey

Directors: C. Martin Wilbur, John W. Hall, Virginia T. Adloff, Norton S. Ginsburg Journal of Asian Studies Advisory Editorial Board: W. Norman Brown, Wilfred Malenbaum, Samuel E. Martin, McKim Marriott

Monographs of the Association for Asian Studies Editorial Board: Frederick W. Mote, Lauriston Sharp, Stephen N. Hay, Norton S. Ginsburg 
Nominating Committee: W. Theodore deBary (Chairman), Cora DuBois, Karl J. Pelzer, Milton B. Singer, Joseph K. Yamagiwa (including continuing members)

Program Committee: John F. Cady (Chairman), Eugene P. Boardman (Vice-Chairman), John D. Eyre, Wilma C. Fairbank, William Henderson, Warren S. Hunsberger, Richard D. Lambert, Charles Wolf, Mary C. Wright (including continuing members)

The following papers were presented at the annual meeting:

\section{Tuesday morning, April 1}

Chinese Historiography. Charles S. Gardner, Chairman; Hans H. Frankel (California), "Objectivity and Bias in Medieval Chinese Historiography"; William Hung (Harvard), "Some Problems in the Last Chapter of Liu Tzu-hsuan's Study of Historiography"; Discussion: Lien-sheng Yang (Harvard).

Summer Programs on Asia for Non-Specialists. Ronald S. Anderson (Michigan), Chairman; Ralph Braibanti (Duke), "Summer Program in Asian Studies at Duke University"; Hyman Kublin (Brooklyn), "Workshop on the Far East at Brooklyn College"; Ward Morehouse (Asia Society), "Survey of Summer Programs on Asia for Non-Specialists"; Paul C. Sherbert (Asia Society), "A Proposal for the Planned Development of Summer Programs on Asia for Non-Specialists."

Rates and Patterns of Industrial Growth in Modern China. Alexander Eckstein (Harvard), Chairman; Fred Hung (California, Davis), "Rates and Patterns of Industrial Growth in China Proper"; S. H. Chou (Pittsburgh), "Rates and Patterns of Industrial Growth in Manchuria"; Richard Moorsteen (RAND), "Early Patterns of Economic Development in Communist China and in the Soviet Union"; Discussion: Y. L. Wu (Marquette).

Free Elections in Asia: A Comparative Study. John M. Maki (Washington) Chairman; Margaret W. Fisher (California) (read by N. K. Bose) "The Experience with Universal Franchise in India"; Claude A. Buss (Stanford) "The Philippine Election of 1957'; Herbert Feith (Cornell), "The Indonesian Elections of 1955"; Herbert Phillips and David A. Wilson (Cornell), "Elections, Coups and the Political Position in Thailand."

\section{Tuesday afternoon, April 1}

Economic Problems and Developments in Southeast Asia. Warren Hunsberger (Rochester), Chairman; Frank Golay (Cornell), "The Structure of Public Economic Objectives in Countries of Southeast Asia"; David Wurfel (Cornell), "Foreign Aid and Social Reform in Philippine Politics"; Bernard Fall (Howard), "Economic Problems of South Viet-Nam"; Robert Hackenberger (Arizona), "Factors in the Transition from Dry-Rice to Wet-Rice Cultivation."

Transformations in Buddhism in China, Japan and Tibet. Kenneth W. Morgan (Colgate), Chairman; Wing-tsit Chan (Dartmouth), "Transformations in Buddhism in China"; Joseph M. Kitagawa (Chicago), "Transformations in Buddhism in Japan"; Kenneth Ch'en (Harvard), "Transformations in Buddhism in Tibet." Language and Culture. Arthur F. Wright (Stanford), Chairman; John Gumperz (California), "Linguistic and Cultural Diversity in North India"; Samuel E. Martin (Yale), "Speech Levels and Social Structure in Japan and Korea"; James Crump (Michigan), "From Reign-name to Planchette"; Discussion: David S. Nivison (Stanford).

The Teaching of Courses on Asian Civilizations at the College Level. Eugene P. Boardman (Wisconsin), Chairman; Milton B. Singer (Chicago), "The Asian Civilizations Program at Chicago"; Wm. Theodore de Bary (Columbia) "The Columbia College General Education Program in Oriental Studies"; L. A. Peter Gosling (Michigan), "The General Course on Asian Civilizations at Michigan"; Discussion: Stanley Spector (Washington).

\section{Wednesday morning, April 2}

Aspects of Cultural Change in Indonesia. Cora DuBois (Harvard), Chairman; Ruth McVey (Cornell), "The Comintern and the Indonesian Independence Movement"; Claire Holt (Cornell), "The Arts in Contemporary Indonesia" (illustrated).

Economic Retardation and Growth in NineteenthCentury China. William W. Lockwood (Princeton), Chairman; K. C. Liu (Harvard), "Houqua; The Sources and Disposition of his Wealth"; Frank King (Harvard), "The Role of NonTrading Enterprises in the Economic Development of Shanghai"; Albert Feuerwerker (Toronto), "Chinese Communist Studies on $\mathrm{Ch}$ 'ing 
Economic History: A Review and Appraisal." Village and State in India. Nirmal $\mathbf{K}$. Bose (Calcutta), Chairman; Richard L. Park (California), "Anthropology and the Study of Indian Politics"; Percival Spear (California), "Village Administration under British Rule"; Burton Stein (Chicago), "The State and the Temple in Medieval South India: Village Agricultural Development"; Discussion: McKim Marriott (Chicago), Merrill Goodall (Claremont).

Japan in Transition. George Beckmann (Kansas), Chairman; Albert Craig (Massachusetts), "The Choshu Civil War"; Marius Jansen (Washington), "Takechi Zuisan and the Tosa Loyalists"; Roger Hackett (Northwestern), "Nishi Amane, a Tokugawa-Meiji Bureaucrat."

\section{Wednesday afternoon, April 2}

American Library Resources for Research on Asia. (A Joint Session with the American Oriental Society.) Horace I. Poleman (Library of Congress), Chairman; T. H. Tsien (Chicago), "China"; G. Raymond Nunn (Michigan), "Japan"; Cecil Hobbs (Library of Congress), "Southeast Asia"; Horace I. Poleman (Library of Congress), "South Asia"; Harry W. Hazard, "The Near East."

Asian Biographical Studies. James T. C. Liu (Pittsburgh), Chairman; Woodbridge Bingham and Hans H. Frankel (California), "China, A.D. 220-960"; Franz Michael (Washington), "Nineteenth and Twentieth Century China"; Melville T. Kennedy (Columbia), "Contemporary China"; Stephen N. Hay (Chicago), "Modern India"; Waiter S. Perry (Colorado), "Japanese Biographies."

\section{The Specialist Session}

Chinese Poetry and Literature. James Crump (Michigan), Chairman; Olga Lang (Swarthmore), "Russian Influence on Modern Chinese Literature, with Special Reference to $\mathrm{Pa}$ Chin"; $\mathrm{Li}$ Chi (California), "Tai-yu and yin-yu in Chinese Poetry"; Lo-shu Fu (Chicago), " 'Helen' of China, a New Interpretation of an Old Romance."

Studies of Mainland China. Yuan-li Wu (Marquette), Chairman; Franklin Houn (Michigan State), "Chinese Communist Control of the Press"; Chao Kuo-chün (Harvard), "Major Developments and Problems in China's Agriculture Today"; John Carter Vincent (Harvard),
"Some Dilemmas of Extraterritoriality in China in its Final Phase"; Yuan-li Wu (Marquette), "Mainland China's Trade with other Asian Countries: Its Nature and Design"; Wen-djang Chu (Yale), "The Finance of the Expeditionary Forces of Tso Tsung-t'ang in Northwest China." Soviet Studies of Asia: An Appraisal. George B. Carson (American Historical Association), Chairman; Paul Langer (Southern California), "The Soviet Far Eastern Specialist"; Peter Berton (Southern California), "Post-War Soviet Research and Publication on Asia."

Studies of Central and Northern Asia. Claude Buss (Stanford), Chairman; Robert A. Rupen (Bryn Mawr), "The City of Ulan Bator."

A Biographical Dictionary of the Ming Period. Arthur W. Hummel, Chairman; Discussion: John K. Fairbank (Harvard); L. Carrington Goodrich (Columbia); Frederick W. Mote (Princeton).

Problems in India's Economic Development. Burton Stein (Chicago), Chairman; Daniel L. Spencer (Southern Illinois), "New Sources of Industrial Finance in India"; Harry J. Friedman (Michigan State), "Division of Responsibility between Centre and States for Development of Industry"; Discussion: Morris D. Morris (Washington).

Area Study Programs: Problems and Potentialities. Richard L. Park (California), Chairman; Discussion: Ernest Bender (Pennsylvania); John W. Hall (Michigan); George McT. Kahin (Cornell); C. Martin Wilbur (Columbia).

Southeast Asian Research: Status, Prospects and Needs. Frank N. Trager (Council on Foreign Relations), Chairman; William Henderson (Council on Foreign Relations), "United States Foreign Policy and Southeast Asia"; Frank M. LeBar (HRAF), "Anthropological Research on Southeast Asia with Special Reference to the HRAF Files"; Guy Pauker (California), "Government and Politics of Southeast Asian Countries"; Robert Van Niel (Russell Sage), "Southeast Asian Historical Research"; Charles Wolf (RAND) "Southeast Asian Economic Research"; John F. Cady (Ohio), "Comments on 'South Asian Research Resources, India Office Library and Public Record Office, London'"; Discussion: Lauriston Sharp (Cornell).

National Income and Product Estimates for Mainland China: A Review and Appraisal. Carl Remer (Michigan), Chairman; Discussion: T. C. 
Liu (International Monetary Fund); K. C. Yeh (RAND); Chang Twanmo (RAND); Alexander Eckstein (Harvard); Y. C. Yin (Harvard); Helen Yin (Harvard).

Christianity in Asia. James R. McGovern (Loyola), "The Position of Christianity in Totalitarian Japan in the Period 1931-1941"; G. Robina Quale (Albion), "Missionaries and Chinese Disputes, 1900-1920."

Diplomatic Considerations. Theodore McNelly (Maryland), "The Japanese Constitution in the Cold War"; Irwin J. Schulman (Columbia), "The Sino-Russian Agreements of 1896."

Selected Asian Career Studies. H. Peter Chen (Harvard), "Nishi Amane (1829-1897) and the Ethos of the Japanese Imperial Forces"; Samuel C. Chu (HRAF), "The Entrepreneurial and Non-Entrepreneurial Aspects of Pioneer Asian Modernizers: The Career of Chang Chien (18531926)."

James K. Irikura (Yale), "Southeast Asia and Japan: Trade and Diplomacy (1580-1623)." Tingsen S. Wei (Harvard-Yenching), "Yayoi Culture-The First Chinese Culture Found in Japan."

Hide Shohara (Michigan), "Cultural Significance of Western Loan Words in Spoken Japanese."

\section{Thursday morning, April 3}

Political Developments in Southeast Asia. John F. Cady (Ohio), Chairman; Harry Benda (Rochester), "The Intellectual as Maker of History in Southeast Asia"; John Brohm (Harpur), "Religious Revivalism in Burma"; Norman Parmer (Maryland), "Recent Constitutional Changes in Malaya"; Josef Silverstein (Cornell), "The Shan States Secession Issue."

New Studies of Ming History. L. Carrington Goodrich (Columbia), Chairman; Lo Jung-pang (Washington), "Withdrawal of Chinese Naval Activity during the Mid-Ming Period"; John Meskill (Northwestern), "A Korean Traveller's Notes on Ming at Mid-Dynasty"; Frederick W. Mote (Princeton), "The Economic Basis of Ming T'ai-tsu's Strength, 1356-67"; Discussion: Wolfgang Franke (Hamburg).

South Asia in Transition. Robert I. Crane (Michigan), Chairman; Richard Lambert (Pennsylvania), "Variations in Labor Force Characteristics in Five Factories in Poona"; Frank J.
Moore (Pan American Airways), "Land Reform and Economic Planning in Nepal"; Thomas Rusch (Asia Foundation), "The Influence of Traditionalist and Non-Political Factors on the Political Process in South Asia."

Russian Interest in Korea. Shannon McCune (Massachusetts), Chairman; Warren Smith, Jr., "Circumstances of the First Russian-Korean Contacts"; Ross H. Macdonald (Toronto), "Russian Scholarship on Korea in the Nineteeth Century"; Glenn D. Paige (Northwestern), "Korean Studies in the Soviet Union"; Discussion: Gregory Henderson (State Department).

\section{Thursday afternoon, April 3}

Tradition and Innovation in Oriental Art (illustrated). A Joint Session with the American Oriental Society. Aschwin Lippe (Metropolitan Museum of Art), Chairman; Participants: Briggs Buchanan; Joseph Campbell (Sarah Lawrence); Oleg Grabar (Michigan); Nelson Wu (Yale).

Asian Religions: The Worshipper and his Ritual Group. Morris E. Opler (Cornell), "Religious Functions of the Family in North Central India"; Pauline Mahar (Cornell), "Changing Religious Practices of an Untouchable Caste"; C. K. Yang (Pittsburgh), "Magic and EthicoPolitical Values in Local Worship of Deified Men"; Louis M. J. Schram, "Impact of Asian Religions (Shamanism, Lamaism, and Taoism) on Monguor Society"; William F. Lebra (Pittsburgh), "Community Religion and Local Lineages in Okinawa."

Business Enterprise in India and Japan. Warren S. Hunsberger (Rochester), Chairman; William W. Lockwood (Princeton), "The Socialistic Society': India and Japan"; Laurence P. Dowd (Michigan), "Business Factors in Current Japanese Economic Development"; Discussion: Edna Ehrlich (Federal Reserve Bank of New York).

Varying Approaches to Meiji History. Hyman Kublin (Brooklyn), Chairman; Harry Harootunian (Penn State), " 'The Progress of Japan' and the Samurai"; Ronald Dore (British Columbia), "The Landlord in Fact and Fiction"; George Beckmann (Kansas), "The Ronoha and the Meiji Restoration"; Discussion: John Harrison (Florida). 